\title{
Arsitektur Sistem Kecerdasan Pengambilan Keputusan di Pondok Pesantren
}

\author{
Rofi'ul Khasanah ${ }^{1}$, Nabila Maulida ${ }^{2}$, Layla Qomariyah ${ }^{3}$, Muhammad Ainul Yaqin ${ }^{4}$ \\ Jurusan Teknik Informatika, Universitas Islam Negeri Maulana Malik Ibrahim, Indonesia \\ ${ }^{1} 17650039 @$ student.uin-malang.ac.id; ${ }^{2} 17650034 @$ student.uin-malang.ac.id; ${ }^{3} 17650048 @$ student.uin-malang.ac.id; \\ 4yaqinov@gmail.com; \\ * corresponding author
}

ARTIKEL INFO

Sejarah Artikel

Diterima: 15 Desember 2020

Direvisi: 29 Juni 2021

Diterbitkan: 30 Agustus 2021

Kata Kunci

Arsitektur Sistem Kecerdasan Sistem Pendukung Keputusan TOGAF

\section{ABSTRAK}

Pondok pesantren merupakan suatu lembaga pendidikan keagamaan yang mana didalamnya mengajarkan serta mengamalkan pendidikan khususnya yang berbasis agama islam. Dalam pengambilan keputusan di pondok pesantren terdapat banyak pada proses bisnisnya. Yang mana terkadang masih banyak keputusan yang kompleks karena proses dalam pengambilan keputusan nya masih secara manual. Sehingga hasil dari keputusan tersebut kurang efektif dan juga kurang efisien. Pada penelitian ini kami akan menjelaskan proses dalam melakukan sebuah sistem arsitektur sistem kecerdasan pengambilan keputusan dengan implementasi sebuah pondok pesantren. Dalam melakukan proses bisnis dalam pondok pesantren menggunakan data proses prosedur bisnis dengan 52 standar minimal pondok pesantren. Hasil akhir dari penelitian ini yaitu berupa arsitektur sistem kecerdasan pengambilan keputusan di pondok pesantren, yang mana dapat digunakan sebagai titik acuan dlam melakukan suatu proses bisnis kegiatan pada pondok pesantren. Dengan demikian adanya arsitektur sistem kecerdasan pengambilan keputusan ini, setiap pelaksanaan kegiatan pada pondok pesantren dapat terstruktur serta dapat meningkatkan kualitas yang ada pada pondok pesantren sesuai dengan tujuan yang diharapkan.

\section{PENDAHULUAN}

Pondok pesantren ialah sebuah pendidikan tradisional yang pelajarnya (santri) nya bermukim bersama dan belajar dengan bimbingan guru secara langsung biasa disebut kiai. Kiai merupakan sebutan bagi seorang pengasuh, pengajar, pembina di dalam sebuah pondok pesantren. Pesantren bisa disebut dengan peradaban pendidikan bagi para umat islam, karena sebagai lembaga pendidikan dan pengajaran agama yang kini telah tersebar luas di penjuru tanah air, diantaranya dengan banyaknya pesantren-pesantren di pelosokpelosok negeri. Pondok pesantren masuk dalam deretan pilihan orang tua untuk studi anakanaknya. Pondok pesantren mempunyai proses bisnis yang sudah ditetapkan seperti penerimaan santri baru, guru, staf dll. Atas dasar proses bisnis yang dimiliki oleh pondok pesantren, perlu nya sebuah keputusan yang diambil agar dapat memenuhi tujuan dari pondok pesantren.

Sebuah pengambilan keputusan dalam proses bisnis di pondok pesantren tidak jarang dalam pengambilan sebuah keputusan terhadap proses bisnis yang telah ada dilakukan dalam bentuk manual. Proses secara manual, tiidak dipungkiri akan memakan proses yang cukup lama, dan kemungkin selanjutnya bahwa hasil yang didapat kurang efektif [1]. Perkembangan teknologi yang kian meningkat, mendorong untuk kemajuan dalam segala bidang tak terkecuali bidang pendidikan untuk mampu ikut serta dalam meningkatkan 
mutu dalam sebuah pengambilan keputusan untuk pondok pesantren. Transformasi dari manual menuju sebuah sistem otomatisasi yang digunakan untuk sebuah pengambilan keputusan yaitu disebut Decision Support System (DSS) atau Sistem Pendukung Keputusan (SPK)

Sistem pendukung keputusan yang menjadi tahapan awal yaitu membuat sebuah arsitektur untuk dilakukan perencanaan sebelum dilakukan eksekusi dalam bentuk program sistem kecerdasan pengambilan keputusan. Pengambilan sebuah sistem pendukung keputusan yaitu dilakukan dengan algoritma dan perhitungan metode seperti Simple Additive Weighting (SAW), Weighted Product (WP), Fuzzy Logic, Genetic Algorithm (GA), Technique for Others Reference of Similarity to Ideal Solution (TOPSIS), Analytical Hirarchy Process (AHP), VIKOR dan ARAS. Perlunya pembangunan sebuah arsitektur berdasarkan metode dan jenis keputusan, guna diimplementasikan di pondok pesantren untuk proses pengambilan keputusan yang menjauhi kata tidak tepat dalam hasil kepuusan.

Pada penelitian ini akan menjabarkan proses pembangunan arsitektur sistem cerdas pendukung keputusan di pondok pesantren. Tujuan dalam penelitian ini adalah mampu meningkatkan daya guna terhadap proses bisnis yang telah ada di pondok pesantren guna membantu untuk tercapainya tujuan pondok pesantren.

\section{METODE}

\section{Pengumpulan Data}

Penelitian ini menautkan sebuah data yang berupa data rinci secara real di lapangan. Data yang telah ada dikembangkan, diciptakan untuk menemukan sebuah konsep atau teori. Teknik penghimpunan data yang dikenakan pada penelitian kualitatif yaitu mengutamakan penggunaan wawancara dan observasi. Menurut [2], yakni berdasarkan sumber didapatkan suatu data, ada dua jenis data diantaranya data primer dan data sekunder. Yang dinamakan data primer adalah data yang dikumpulkan oleh peneliti secara langsung dengan melakukan penelitian di lapangan. Sedangkan yang dinamakan data sekunder yaitu suatu data yang dikumpulkan dari beberapa sumber yang telah dipublikasikan. Data primer yang digunakan pada penelitian ini adalah suatu struktur organisasi pondok pesantren yang didapatkan dari studi dokumen pesantren. Kemudian untuk data sekunder yaitu penyesuaian dari standar minimum pondok pesantren dalam pelaksanaan proses bisnis pada pondok pesantren, yang dikelompokkan menjadi 5 kelompok.

\section{Analisis Data}

Pada penelitian ini menggunakan teknik analisis data deskriptif kualitatif dengan cara menentukan titik pengambilan keputusan dengan menggunakan metode sistem pendukung keputusan yang dilakukan sesuai Standar Minimum Pondok Pesantren yang telah dirumuskan. Titik titik keputusan didapatkan dari hasil analisis prosedur atau dalam proses suatu bisnis yang terjadi pada pondok pesantren untuk menentukan titik keputusan. Hasil analisa tersebut berbentuk tabel yang berisi metode, titik keputusan dan penjelasan penyelesaian masalah yang ada di pondok pesantren berdasarkan standar minum pondok pesantren.

Menurut [3], analisis yang digunakan pada penelitian ini yaitu pada analisis deskriptif merupakan suatu teknik menganalisis data berdasarkan faktor - faktor pendukung objek penelitian. Sedangkan pada analisis kualitatif yaitu suatu teknik dalam menganalisis data yang berhubungan dengan pendapat subjek terhadap suatu objek penelitian. 


\section{Implementasi The Open Group Architecture Framework (TOGAF)}

Framework TOGAF dikenakan pada beberapa bidang sesuai bidang perbankan, bidang industri manufaktur serta bidang pendidikan. Dalam mengimplementasikannya, TOGAF dipakai guna mengembangkan Arsitektur Enterprise. Architecture Development Method $(A D M)$ merupakan bentuk untuk membangun, mengelola dan menerapkan arsitektur dan sistem informasi yang memberikan method dan tools yang detail. Framework TOGAF memiliki salah satu kelebihan yaitu sifatnya fleksibel dan bersifat open source. Hal ini yang membedakan antara Framework EA dengan yang lain[4].

ADM merupakan salah satu metode guna peningkatan arsitektur yang dirancang untuk sistem dan kebutuhan organisasi. Salah satu tugas sebelum menerapkan ADM adalah untuk meninjau komponen dalam penerapan kemudian disesuaikan dengan keadaan perusahaan. Urutan fase $\mathrm{ADM}$ bisa disesuaikan sampai batas tertentu tergantung pada kematangan arsitektur dalam pondok pesantren yang bersangkutan dan urutan fase juga dapat didefinisikan oleh prinsip-prinsip bisnis dan arsitektur pondok pesantren.

Pada umumnya, arsitektur terbagi menjadi empat jenis yaitu sebagai himpunan bagian dari arsitektur sistem kecerdasan pengambilan keputusan [5] :

1. Arsitektur Data

Arsitektur data bertujuan untuk mendeskripsikan data yang dibutuhkan pada arsitektur aplikasi. Arsitektur data memaparkan struktur secara sistematis dan fisik aset data organisasi dan sumber daya manajemen data.

2. Arsitektur Aplikasi

Arsitektur aplikasi menyajikan blueprint guna aplikasi sistem tunggal yang akan dipakai, interaksi antar aplikasi serta hubungan setiap aplikasi menggunakan proses bisnis inti organisasi.

3. Arsitektur Teknologi

Arsitektur teknologi menjelaskan tentang infrastruktur perangkat lunak yang ditujukan untuk mendukung penyebaran inti, aplikasi mission-critical.

4. Arsitektur Bisnis

Arsitektur bisnis atau proses bisnis menjelaskan tata kelola, organisasi, strategis bisnis, dan proses bisnis utama.

\section{Sistem Pendidikan Pondok Pesantren}

Dalam memaksimalkan sistem sebuah pendidikan pondok pesantren membutuhkan manajemen yang baik untuk mencapai sasaran yang telah di buat. Manajemen yaitu proses khusus, berisi dari banyak aktivitas; perancangan, penggolongan, penggiatan, dan pengontrolan. Dari penjelasan di atas, bahwa manajemen merupakan ilmu aplikatif, dimana memiliki sebuah proses tindakan mencakup beberapa hal, yaitu :

1. Perencanaan

Fungsi dari perencanaan meliputi pembuatan rencana, penentuan aturan prosedur, standart, penetapan tujuan, dan prediksi apa yang terjadi.

2. Pengorganisasian

Fungsi dari organisasi mencakup beberapa hal, yaitu : pembagian tugas untuk masing-masing pihak, membuat bagian, menetapkan tanggung jawab, mendelegasikan, dan mengkoordinir kerja bawahan.

3. Penggiatan

Fungsi dari penggiatan yaitu menggerakkan kelompok menggunakan sarana komunikasi, pemberian instruksi, kepemimpinan, dan perundingan.

4. Pengawasan 
Fungsi dari pengawasan bisa juga disebut dengan evaluasi. Ketika organisasi sudah berjalan, maka pimpinan harus mengadakan pengawasan agar organisasi berjalan dengan sesuai apa yang direncanakan.

Melalui empat proses tindakan manajemen dapat bergerak. Hal itu juga bergantung pada tingkat kepemimpinan sorang manajer. Salah satu yang harus diperhatikan oleh seorang manajer adalah penetapan tujuan. Hakikat dari tujuan yaitu sebagai landasan dan pedoman dalam proses menjadi seorang manajer. Ada beberapa rumusan tujuan menjadi seorang manajer yang memiliki fungsi menjadi penentuan strategi, sasaran, dan aksi-aksi peraturan organisasi atau pesantren. Guna mewariskan inspirasi dan motivasi bagi pelaksana dan dijadikan standar analisis berkenaan dengan pelaksanaan planning organisasi.

Secara umum, tujuan pondok pesantren adalah menumbuhkan kepribadian santri agar menjadi seorang muslim yang baik, menanamkan rasa keagamaan, mengamalkan ajaranajaran islam serta menjadikan santri menjadi manusia yang berguana bagi nusa, bangsa dan negara. Tujuan pondok pesantren tidaklah untuk mengejar kepentingan kekuasaan, uang dan keagungan dunia, akan tetapi ditanamkan kepada mereka bahwa belajar adalah sematamata kewajiban dan pengabdian kepada Tuhan. Tujuan pendidikan tidak hanya memperluas pikiran santri akan tetapi, mempertinggi moral spiritual, menghargai nilainilai kemanusiaan, mengajarkan sikap dan tingkah laku jujur dan berakhlak. Secara garis besar pendidikan islam bertujuan untuk membina manusia agar menjadi hamba allah yang sholeh dengan seluruh aspek kehidupannya, pikiran, perasaan, dan perbuatannya. Di dalam pondok pesantren terdapat beberapa kurikulum yang dijadikan sebagai acuan belajar dan keberhasilan seorang santri. Kurikulum bertujuan untuk mencetak ulama / generasi baru. Pencapaian keberhasilan seorang santri biasanya tidak dapat menentukan $100 \%$ santri menjadi seorang ulama. Kualitas seorang ulama membutuhkan waktu yang sangat lama untuk dijangkau.

Kurikulum pondok pesantren bersifat fleksibel. Setiap santri dapat menyusun kurikulum sendiri. Kurikulum yang diterapkan tidak mengarah di luar pengetahuan agama. Meskipun pada perkembangannya banyak pesantren yang mengajarkan ilmu umum, tetapi tujuan utama pendidikan di pondok pesantren adalah pemahaman dan penguasaan ilmu agama. Proses belajar mengajar di pondok pesantren biasanya menggunakan metode bandongan dan Sorogan. Bandongan dilakukan dengan cara kyai/guru membacakan kitab yang berbahasa arab dan menerjemahkan dalam bahasa lokal, dan menjelaskan maksud yang terkandung dalam kitab tersebut. Metode ini dilakukan untuk memperluas pengetahuan santri. Sedangkan sorogan dilakukan dengan cara kyai/guru menguji pemahaman santri mengenai kitab yang sudah di pelajari ketika bandongan.

\section{Standar Pondok Pesantren}

Data yang digunakan dalam penelitian ini merupakan suatu alur proses prosedur bisnis pada pondok pesantren. Terdapat 52 standar minimal pondok pesantren menurut Welsh Assembly Government Kementerian Kesehatan dan Pelayanan Sosial pada 2003. Standar miniml pondok pesantren dibagi menjadi 5 kategori diantaranya :

1. Kebijakan Kesejahteraan sesuai dengan Prosedur, yaitu :

a. Menerapkan praktik setiap kegiatan di pondok pesantren

b. Melawan tindakan kekerasan

c. Menerapkan perlindungan terhadap anak / penyalahgunaan

d. Menerapkan perilaku pembatasan, disiplin, hukuman dan penghargaan

e. Merespon setiap keluhan anak

f. Menerapkan pendidikan dalam kesehatan 
g. Melakukan catatan setiap kesehatan santri

2. Manajemen dan Organisasi, yaitu :

a. Membentuk ketua / pemimpin yang jelas

b. Melakukan manajemen secara krisis

c. Membentuk organisasi pada asrama

d. Aktivitas dengan waktu yang bebas

e. Pengamanan pandangan setiap santri

f. Prefek

g. Pengawasan serta dukungan dari pihak luar terhadap santri

3. Pendukung Kesejahteraan Setiap Santri, yaitu :

a. Menyediakan perawatan medis serta pertolongan pertama

b. Melakukan perawatan terhadap santri yang sakit

c. Melakukan manajemen dalam masalah personal dan kesehatan

d. Bersikap adil dalam masalah deskriminasi atau kesempatan

e. Menyediakan ponsel serta kontak setiap wali santri

f. Menjaga uang saku atau hak milik santri dengan baik

g. Pemasukan dan proses pengenalan setiap santri yang baru

h. Menyediakan wali terhadap pendidikan

i. Melakukan pemantauan setiap catatan(monitoring of records)

j. Menyediakan catering

k. Adanya makanan dan minuman

1. Melakukan praktik tindakan dalam pencegahan latihan kebakaran

m. Beban diwajibkan pada setiap santri

n. Penyediaan anak-anak lebih dijaga dibandingkan santri lain

o. Menilai setiap aktivitas yang beresiko tinggi

p. Menyediakan akses informasi serta fasilitas yang ada pada ponpes

4. Pengawasan, yaitu :

a. Melakukan pengawasan pada santri

b. Melakukan pengawasan terhadap santri jika berada diluar ponpes

c. Melakukan pengawasan setiap santri pada malam hari

d. Menjelaskan pengenalan, pelatihan staff dan pengawasan

e. Aturan pelaksanaan kegiatan praktik pengawasan

f. Menjaga baik hubungan antara pengawas dengan santri

g. Menjaga privasi dengan baik

h. Mencalonkan pengawas serta melakukan pemeriksaan terhadap orang lain

i. Menyediakan akses terhadap orang dewasa dengan santri

5. Premis, yaitu :
a. Akomodasi pondok pesantren
b. Keamanan dan akses pada akomodasi
c. Tempat tidur
d. Aturan pembelajaran
e. Aturan toilet dan mencuci
f. Mengganti fasilitas dan ruang ganti
g. Area rekreasi
h. Menilai risiko serta mengamankan suatu bahaya
i. Penyediaan bagi santri yang sedang sakit
j. Menyediakan pencucian pakaian
k. Menyediakan koperasi
1. Melakukan kegiatan yang bersangkutan dengan pondok 
m. Menyediakan pertukaran khusus lokasi luar pondok pesantren

Dari ke-52 standar yang ada, akan dilihat lagi yang membutuhkan dan bisa diberikan sistem cerdas pengambilan keputusan. Standar yang telah dipilih untuk diberikan pengambilan keputusan diberikan metode sistem pengambilan keputusan.

\section{Sistem Pendukung Keputusan (SPK)}

Sistem pendukung keputusan yang dihasilkan metode sebuah keputusan merupakan sebuah adaptasi dari data standar pondok pesantren yang telah dijelaskan. Pengambilan keputusan, salah satu nya dibangun dengan harapan agar mendukung jalan keluar atas sebuah masalah bahkan untuk dijadikan sebagai sebuah peluang. Metode ini diambil dari standar pondok pesantren yang telah ada, dan diambil topik yang membutuhkan sebuah keputusan, tidak seluruh standar yang membutuhkan sebuah pengambilan keputusan.

\section{HASIL DAN PEMBAHASAN}

\section{Menganalisis Titik Keputusan pada Proses Bisnis Sekolah}

1. Kebijakan Kesejahteraan Sesuai dengan Prosedur

a. Penentuan Penanganan Santri yang Melanggar/Bermasalah

Titik keputusan ini berupa penanganan terhadap santri yang melakukan pelanggaran terhadap peraturan yang telah ditetapkan oleh pondok pesantren. Pengambilan keputusan dalam persoalan ini yaitu dengan kriteria-kriteria kedisiplinan terhadap kegiatan sekolah, kegiatan mengaji, kegiatan pembatasan wilayah, tidak melakukan tindak kekerasan, mengikuti setiap kegiatan pondok pesantren. Setiap pelanggaran yang dilakukan diberikan bobot atau poin.

2. Manajemen dan Organisasi

a. Pemilihan Pengurus Pondok Pesantren

Manajemen dan organisasi dalam pondok pesantren harus terus dilakukan dengan cara memilih pengurus pondok pesantren untuk membantu melaksanakan kebijakan dan memajukan pondok pesantren. Pemilihan pengurus diadakan dengan cara pertimbangan terhadap kriteria ketaatan, kedisiplinan, penguasaan terhadap posisi yang diambil.

b. Penentuan waktu aktif dan bebas santri

Pondok pesantren juga memiliki waktu untuk pembelajaran santri. Titik keputusan ini didapatkan hasil berupa hari libur atau bebas santri yang diberikan yaitu 1 hari dalam seminggu, yaitu di hari minggu.

c. Alokasi Dana Pondok Pesantren

Pendanaan di pondok pesantren perlu perkiraan dalam pengalokasian dana atau anggaran. Pada analisa titik keputusan menggunakan data pelaksanaan kegiatan, tingkat kebutuhan dan kondisi.

3. Pendukung Kesejahteraan Setiap Santri

a. Perekaman Kesehatan Santri

Pihak pondok pesantren mencatat atau merekam perihal kesehatan santri agar dapat mengontrol kesehatan sehingga mampu untuk dilakukan pencegahan terhadap santri yang memiliki riwayat penyakit. Perekaman dilakukan dalam 1 bulan $1 \mathrm{x}$ atau $2 \mathrm{x}$ pada masing-masing santri untuk mengetahui perkembangan kesehatan.

b. Penerimaan Santri Baru

Pondok pesantren terus beregenerasi untuk melahirkan bibit-bibit para calon ulama, maka diadakannya penerimaan santri baru. Data/penilaian yang menjadi kriteria-kriteria diterimanya santri yaitu Al-Qur'an (Kelancaran, Kefasihan, Tajwid, Makhorijul Huruf), Kitab, Nilai Ujian Nasional, Sikap (Attitude). 
c. Penentuan waktu menghubungi wali santri

Setiap santri perlu untuk menghubungi wali santri untuk mengabarkan perkembangannya. Pemberian waktu untuk menghubungi wali santri yaitu dengan melihat data santri dan data waktu, agar setiap santri mendapatkan kesempatan untuk menghubungi wali santri.

d. Menentukan pembimbing akademik

Penentuan pembimbing akademik bagi santri dilakukan untuk mengawal pendidikan santri di sekolah maupun di pondok pesantren, agar mampu optimal dalam belajar. Pengambilan keputusan ini melibatkan data guru yang ada dan jumlah santri. Jadi setiap guru bisa membimbing santri lebih dari satu.

e. Menentukan santri teladan/berprestasi

Penghargaan untuk santri yang telah disiplin mengikuti kegiatan dan juga peraturan atau kebijakan di pondok pesantren patut diberikan. Hasil keputusan ini yaitu perangkingan terhadap data yang dimasukkan, diantaranya data kedisiplinan, prestasi, absensi kegiatan, penilaian kegiatan.

f. Penilaian Proses Belajar Mengajar

Guru sebagai tenaga pendidik juga memiliki tugas untuk menjaga mutu dalam pembelajaran. Indikator dalam pengambilan keputusan ini yaitu 1) tingkat kehadiran pengajar, 2) keselarasan mulai dan akhir pembelajaran, 3) kesesuaian materi terhadap silabus, 4) diterima dan dipahami materi, 5) motivasi belajar dan mendalami pelajaran, 6) penggunaan ilustrasi mengajar, 7) perhatian dan komunikasi dua arah, 8) membantu dan akomodatif, 9) pengetahuan terbaru dalam pengajaran. Hasil dari pengambilan keputusan yaitu penilaian proses belajar mengajar.

g. Penentuan ekstrakurikuler minat bakat santri

Kegiatan ekstrakurikuler merupakan sebuah pembelajaran internal yang diadakan oleh pihak sekolah atau pondok pesantren untuk mengembangkan minat dan bakat santri. Hasil dari titik keputusan ini yaitu penempatan santri pada ekstrakurikuler yang sesuai dengan minat dan bakat.

h. Penentuan Kelas/Penjurusan santri

Penjurusan atau penentuan kelas untuk santri didasari agar pembelajaran dapat berjalan dengan maksimal dan optimal. Titik keputusan ini mendapatkan hasil dari tes kemampuan akademik santri, yang nantinya di konversikan menjadi nilai. Nilai dihitung untuk dilakukan untuk membagi santri terhadap tiap-tiap jurusan yang ada.

4. Pengawasan

a. Perekrutan Guru dan Staff

Pondok pesantren memerlukan tenaga pendidik dan staf yang mampu bekerja sama untuk meningkatkan prestasi, memajukan pesantren dan menciptakan calon-calon ulama. Pengambilan keputusan dalam perekrutan guru dan staf diperhatikan dalam kriteria terhadap posisi yang diambil dan juga potensi yang dimiliki.

b. Pengadaan dan Persediaan Inventaris Pondok Pesantren

Inventaris pondok pesantren memerlukan sebuah informasi perihal persediaan dan pengadaan barang dengan tepat. Hasil dari titik keputusan ini yaitu perhitungan persediaan barang dan juga pengadaan.

5. Premis
a. Penentuan destinasi rekreasi santri 
Rekreasi atau kegiatan diluar yang diadakan oleh pondok pesantren untuk santri yaitu dapat diambil keputusan berdasarkan timing kunjungan, biaya kunjungan dan kepuasan pelayanan di destinasi rekreasi. Hasil dari pengambilan keputusan yaitu perangkingan terhadap destinasi wisata.

\section{Menentukan Metode Pengambilan Keputusan pada Proses Bisnis Pondok Pesantren}

Standar pondok pesantren memiliki 52 buah yang terangkum atau digolongkan menjadi 5 kategori yang didalamnya memiliki sub kategori atau isi dari 52 standar. Standar yang dimiliki oleh pondok pesantren tidak menyeluruh membutuhkan sebuah sistem cerdas pendukung keputusan, jadi penulis harus menganalisa, titik yang dapat dijadikan sistem cerdas pendukung keputusan atau pengambilan keputusan. Hasil analisa titik keputusan pada proses bisnis pondok pesantren sebagai berikut :

Tabel 1. Hasil analisis titik keputusan serta metode SPK yang digunakan

\begin{tabular}{|c|c|c|c|}
\hline No & Titik Keputusan & Metode & Referensi \\
\hline \multicolumn{4}{|c|}{ Kebijakan Kesejahteraan Sesuai dengan Prosedur } \\
\hline 1 & $\begin{array}{lr}\text { Penentuan } & \text { Penanganan } \\
\text { Santri yang } & \text { yang } \\
\text { Melanggar/Bermasalah }\end{array}$ & $\begin{array}{l}\text { Metode Simple Additive } \\
\text { Weighting (SAW), } \\
\text { Technique For Other } \\
\text { Reference by Similarity } \\
\text { to Ideal Solution } \\
\text { (TOPSIS) }\end{array}$ & $\begin{array}{l}\text { Penelitian[6] menggunakan metode Simple } \\
\text { Additive Weighting (SAW) dengan } \\
\text { memberikan keputusan penanganan terhadap } \\
\text { santri, Pada penelitian Sistem Pendukung } \\
\text { Keputusan untuk Menentukan Tingkat } \\
\text { Kedisiplinan dan Sanksi Pelanggaran Siswa[7], } \\
\text { indikatornya menggunakan perhitungan poin } \\
\text { pelanggaran. }\end{array}$ \\
\hline \multicolumn{4}{|c|}{ Manajemen dan Organisasi } \\
\hline 2 & $\begin{array}{l}\text { Pemilihan Pengurus } \\
\text { Pondok Pesantren }\end{array}$ & $\begin{array}{l}\text { Metode Simple Additive } \\
\text { Weighting (SAW) }\end{array}$ & $\begin{array}{l}\text { Penelitian[8] menggunakan metode Simple } \\
\text { Additive Weighting (SAW) dalam pengambilan } \\
\text { keputusan pemilihan pengurus inti dan anggota } \\
\text { baru }\end{array}$ \\
\hline 3 & $\begin{array}{l}\text { Penentuan Waktu Aktif } \\
\text { dan Bebas Santri }\end{array}$ & $\begin{array}{l}\text { Technique for Other of } \\
\text { Preference by Similarity } \\
\text { to Ideal Solution } \\
\text { (TOPSIS) }\end{array}$ & $\begin{array}{l}\text { Penelian[9] dalam penentuan hari libur } \\
\text { pegawai menggunakan metode TOPSIS. }\end{array}$ \\
\hline 4 & $\begin{array}{l}\text { Alokasi Dana Pondok } \\
\text { Pesantren }\end{array}$ & 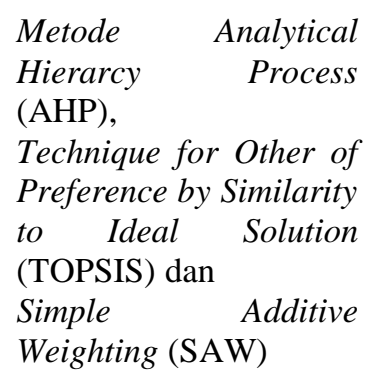 & $\begin{array}{l}\text { Penelitian[10] menggunakan metode AHP dan } \\
\text { TOPSIS untuk pengambilan keputusan } \\
\text { penentuan alokasi dana kegiatan pada studi } \\
\text { kasus kegiatan mahasiswa politeknik negeri } \\
\text { padang, dan } \\
\text { Pada penelitian[11] menggunakan metode } \\
\text { SAW dalam pengambilan keputusan alokasi } \\
\text { anggaran dana bantuan operasional sekolah di } \\
\text { SMP Negeri } 3 \text { Satu Atap Bangun Purba. }\end{array}$ \\
\hline \multicolumn{4}{|c|}{ Pendukung Kesejahteraan Setiap Santri } \\
\hline 5 & $\begin{array}{l}\text { Perekaman } \\
\text { Santri }\end{array}$ & $\begin{array}{l}\text { Simple Additive Attribut } \\
\text { (SAW) }\end{array}$ & $\begin{array}{l}\text { Penelitian[12] dalam pengambilan keputusan } \\
\text { penanganan pasien UGD dengan menggunakan } \\
\text { metode SAW pada studi kasus di Puskesmas } \\
\text { Gajahan Surakarta. }\end{array}$ \\
\hline 6 & Penerimaan Santri Baru & Fuzzy Tahani & Penelitian[13] menggunakan metode Fuzzy \\
\hline
\end{tabular}




\begin{tabular}{|c|c|c|c|}
\hline & & & $\begin{array}{l}\text { Tahani yang hasilnya berupa perangkingan } \\
\text { terhadap nilai calon santri di pondok pesantren } \\
\text { sarochaniyyah. }\end{array}$ \\
\hline 7 & $\begin{array}{l}\text { Pemberian Waktu } \\
\text { Menghubungi Wali Santri }\end{array}$ & $\begin{array}{l}\text { Analytical Hierarchy } \\
\text { Process (AHP), Genetic } \\
\text { Algorithm (GA) }\end{array}$ & $\begin{array}{l}\text { Penelitian[14] menggunakan metode AHP } \\
\text { dalam pengambilan suatu keputusan untuk } \\
\text { menentukan waktu kerja karyawan dan } \\
\text { Pada penelitian[15] dalam pengambilan } \\
\text { keputusan untuk penetapan jadwal kuliah yang } \\
\text { menggunakan metoda GA yang diperoleh dari } \\
\text { hasil nilai fitness terbaik. }\end{array}$ \\
\hline 8 & $\begin{array}{l}\text { Menentukan Pembimbing } \\
\text { Akademik }\end{array}$ & $\begin{array}{l}\text { Simple Additive } \\
\text { Weighting (SAW) }\end{array}$ & $\begin{array}{l}\text { Penelitian[16] dalam penentuan } \\
\text { pembimbing skripsi menggunakan metode } \\
\text { SAW. }\end{array}$ \\
\hline 9 & $\begin{array}{l}\text { Menentukan Santri } \\
\text { Teladan/Berprestasi }\end{array}$ & $\begin{array}{l}\text { Analytical Hierarchy } \\
\text { Process (AHP), VIKOR } \\
\text { dan Technique for } \\
\text { Other of Preference by } \\
\text { Similarity to Ideal } \\
\text { Solution (TOPSIS), dan } \\
\text { metode ARAS }\end{array}$ & $\begin{array}{l}\text { Penelitian[17] menggunakan metode AHP } \\
\text { dalam topik pemilihan santri berprestasi di } \\
\text { pondok pesantren assyafi'iyyah kediri, } \\
\text { Penelitian[18] pada siswi berprestasi studi } \\
\text { kasus di SD Negeri Margamulya dengan } \\
\text { menggunakan metode AHP, } \\
\text { Pada Penelitian[19] yang menggunakan metode } \\
\text { VIKOR dan TOPSIS pada topik pemilihan } \\
\text { siswa berprestasi di sekolah menengah } \\
\text { pertama, dan } \\
\text { Pada penelitian[20] dalam pemilihan santri } \\
\text { terbaik di madrasah aliyah swasta yang } \\
\text { menggunakan metode ARAS yang hasilnya } \\
\text { berupa perangkingan. }\end{array}$ \\
\hline 10 & $\begin{array}{l}\text { Penilaian Proses Belajar } \\
\text { Mengajar }\end{array}$ & $\begin{array}{l}\text { Simple Additive } \\
\text { Weighting (SAW) }\end{array}$ & $\begin{array}{l}\text { Penelitian[21] menggunakan metode Simple } \\
\text { Additive Weighting (SAW) untuk pemilihan } \\
\text { keputusan pada penilaian proses belajar } \\
\text { mengajar. }\end{array}$ \\
\hline 11 & $\begin{array}{l}\text { Penentuan Ekstrakurikuler } \\
\text { Minat Bakat Santri }\end{array}$ & $\begin{array}{l}\text { Simple Additive } \\
\text { Weighting (SAW) }\end{array}$ & $\begin{array}{l}\text { Penelitian pada penentuan kegiatan } \\
\text { ekstrakurikuler sesuai dengan bakat dan } \\
\text { minat[22] menggunakan metode SAW yang } \\
\text { digunakan untuk mencari alternatif yang } \\
\text { optimal dari alternatif pada kriteria. }\end{array}$ \\
\hline 12 & $\begin{array}{l}\text { Penentuan } \\
\text { Kelas/Penjurusan Santri }\end{array}$ & $\begin{array}{l}\text { Weighted Product } \\
(\mathrm{WP}), \text { Model Yager dan } \\
\text { Multifactor Evaluation } \\
\text { Process }\end{array}$ & $\begin{array}{l}\text { Penelitian[23] dalam studi kasus SMA Negeri } 1 \\
\text { Pakusari dalam pemilihan penjurusan yang } \\
\text { menggunakan metode WP dengan menghitung } \\
\text { skor dan pembobotan, yang bertujuan untuk } \\
\text { mengklasifikasikan sesuai jurusan, } \\
\text { Pada penelitian[23] menggunakan model Yager } \\
\text { untuk pemilihan jurusan di SMA, dan } \\
\text { Penelitian[24] menggunakan metode } \\
\text { Multifactor Evaluation Process pada } \\
\text { pengambilan keputusan penjurusan siswa SMA } \\
\text { Negeri } 3 \text { Bondowoso. }\end{array}$ \\
\hline \multicolumn{4}{|c|}{ Pengawasan } \\
\hline 13 & Perekrutan Guru dan Staf & $\begin{array}{l}\text { Analytical Hierarchy } \\
\text { Process (AHP) }\end{array}$ & $\begin{array}{l}\text { Penelitian[25] menggunakan metode AHP } \\
\text { dalam perekrutan guru di MI Irsyaduthalibin } \\
\text { Sukabumi dengan kriteria kualifikasi }\end{array}$ \\
\hline
\end{tabular}




\begin{tabular}{|c|l|l|l|}
\hline & & & $\begin{array}{l}\text { akademik, wawancara, tes mengajar dan } \\
\text { disesuaikan dengan posisi yang di lamar. }\end{array}$ \\
\hline 14 & $\begin{array}{l}\text { Pengadaan dan Persediaan } \\
\text { Inventaris Pondok } \\
\text { Pesantren }\end{array}$ & $\begin{array}{l}\text { Economic Order } \\
\text { Quantity (EOQ) dan } \\
\text { Period Order Quantity } \\
\text { (POQ) }\end{array}$ & $\begin{array}{l}\text { Penelitian[26] dalam pengambilan keputusan } \\
\text { untuk pengendalian persediaan bahan baku } \\
\text { dalam studi kasus PT. Batarasura Mulia. }\end{array}$ \\
\hline 15 & $\begin{array}{l}\text { Penentuan } \\
\text { Rekreasi Santri Destinasi }\end{array}$ & $\begin{array}{l}\text { Technique for Other of } \\
\text { Preference by Similarity } \\
\text { to Ideal Solution } \\
\text { (TOPSIS) } \\
\text { dan Weighted Product } \\
\text { (WP) }\end{array}$ & $\begin{array}{l}\text { Penelitian[27] menggunakan metode TOPSIS } \\
\text { perangkingan, } \\
\text { Penelitian[28] menggunakan metode WP untuk } \\
\text { pemilihan destinasi wisata favorit. }\end{array}$ \\
\hline
\end{tabular}

\section{Arsitektur Sistem Cerdas Pengambilan Keputusan di Pondok Pesantren}

Arsitektur sistem cerdas di pondok pesantren mempunyai beberapa tahapan dan bagian dalam menyelesaikan penelitian. Arsitektur sistem cerdas menghubungkan antara poin atau titik keputusan dengan metode yang ada untuk penyelesaian pengambilan keputusan. Dari hasil analisa titik keputusan dan metode pengambilan keputusan didapatkan hasil untuk penyelesaian masalah yang ada. Arsitektur sistem cerdas dalam penelitian ini dapat dillihat pada Gambar 1 sebagai berikut:

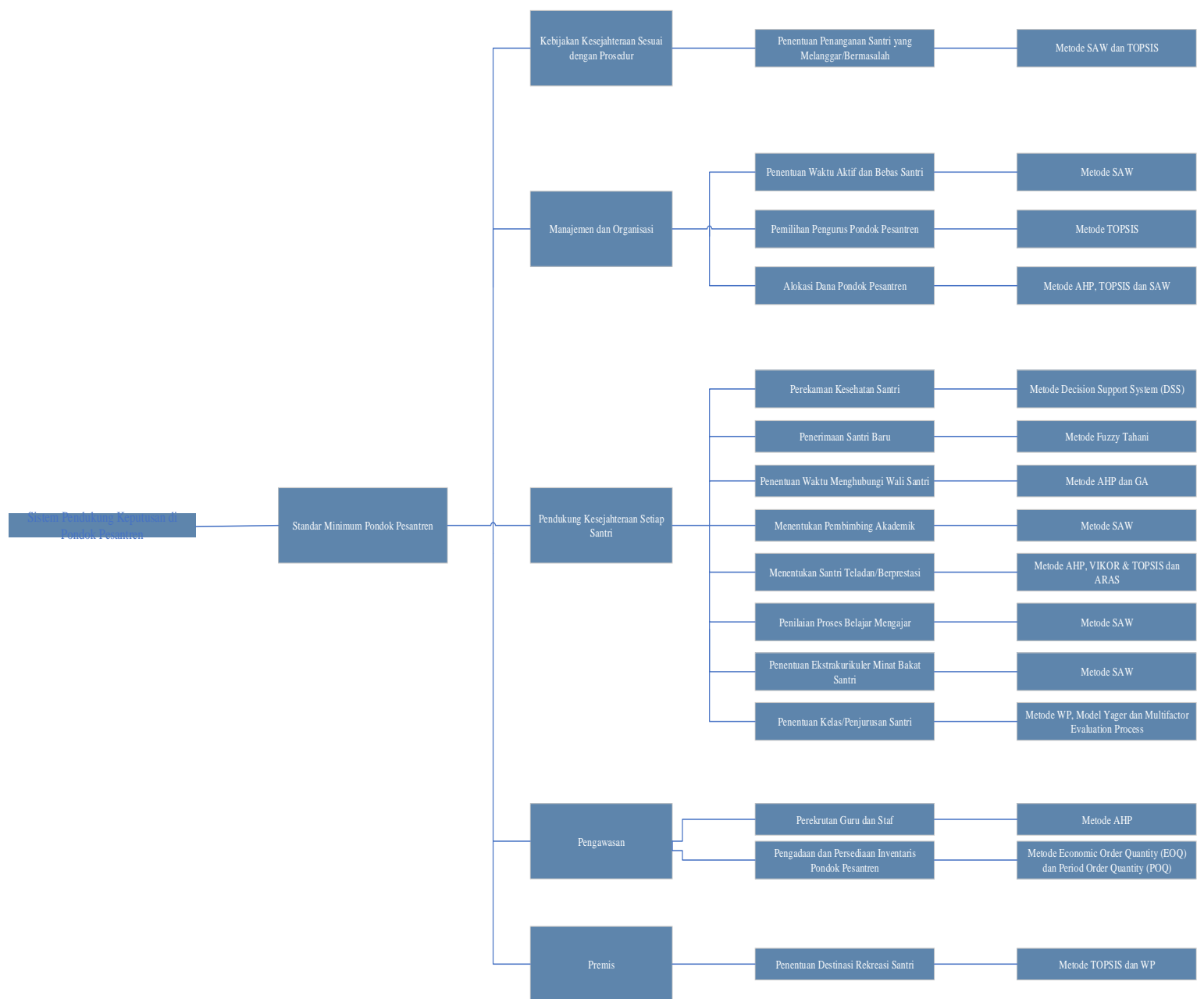

Gambar 1. Bagan Sistem Pendukung Keputusan di dalam Pondok Pesantren 


\section{KESIMPULAN}

Kesimpulan pada penelitian ini adalah analisis dari titik keputusan yang diambil dari standar minimum dari pondok pesantren yang berjumlah 52 poin. Titik keputusan yang telah ditetapkan akan diberikan sebuah metode sistem pendukung keputusan. Arsitektur ini merupakan bentuk untuk memudahkan pondok pesantren dalam membuat sebuah keputusan yang sulit ditemukan. Penelitian ini juga dibentuk dengan konsep atau model bisnis. Berdasarkan penelitian ini, peneliti mengusulkan sebuah sistem pendukung keputusan untuk titik keputusan yang telah dianalisa untuk dijadikan solusi dari permasalahan. Hasil dari arsitektur sistem kecerdasan pengambilan keputusan pada penelitian ini merupakan sebuah graph atau bagan. Dengan adanya penelitian Arsitektur Sistem Kecerdasan Pengambilan Keputusan di Pondok Pesantren diharapkan dapat digunakan atau dimanfaatkan untuk pengambilan keputusan pada titik keputusan di pondok pesantren. Diharapkan agar memudahkan dalam pembuatan program atau sistem pendukung keputusan oleh pondok pesantren. Hasil dari penelitian ini masih sederhana, karenanya masih memerlukan sebuah pengembangan secara kontinu yang lebih baik.

\section{REFERENSI}

[1] Saefudin and S. Wahyuningsih, "Sistem Pendukung Keputusan Untuk Penilaian Kinerja Pegawai Menggunakan Metode Analytical Hierarchy Process (Ahp) Pada RSUD Serang,” J. Sist. Inf., vol. 1, no. 1, p. 33, 2014.

[2] D. Nofriansyah, Konsep Data Mining Sistem Pendukung Keputusan, 1st ed. Yogyakarta: Deepublish.

[3] E. P. R. Lestari, H. P. Titania, A. S. 'Ulia Dewi, and M. A. Yaqin, "Pengembangan Arsitektur Model Proses Bisnis Pada Pondok Pesantren," Jurasik (Jurnal Ris. Sist. Inf. dan Tek. Inform., vol. 5, no. 1, p. 77, 2020.

[4] R. Weisman, “An Overview of TOGAF Version 9.1,” Publ. by Open Gr., p. 43, 2011.

[5] R. B. R. Rosida, A. W. Hanifah, F. D. Adzkiya, and M. A. Yaqin, "Pertumbuhan Kebutuhan Pondok Pesantren Menggunakan Graph," Jurasik (Jurnal Ris. Sist. Inf. dan Tek. Inform., vol. 5, no. 1, p. 7, 2020.

[6] P. Kasih and Y. Lestari, "Aplikasi Penghitung Point Pelanggaran Siswa Sebagai Sistem Pendukung Keputusan Bagi Badan Konseling Sekolah Dengan Simple Additive Weighting ( Studi Kasus : SMK N 1 Tanah Grogot-Kaltim )," Nusant. Eng., vol. 2, no. 1, pp. 57-64, 2009.

[7] Handayani and U. Fadlilah, "Sistem Pendukung Keputusan untuk Menentukan Tingkat Kedisiplinan dan Sanksi Pelanggaran Siswa," J. Chem. Inf. Model., vol. 53, no. 9, pp. 1689-1699, 2019.

[8] L. Licantik, W. Widiatry, and Pebriana Lorenza, "Sistem Penunjang Keputusan Pemilihan Pengurus Inti Dan Anggota Baru Menggunakan Metode Simple Additive Weighting (Saw) Berbasis Website (Studi Kasus: Himpunan Mahasiswa Teknik Informatika Universitas Palangka Raya)," J. Teknol. Inf. J. Keilmuan dan Apl. Bid. Tek. Inform., vol. 13, no. 1, pp. 58-67, 2019.

[9] M. I. Dwipayani, A. S. Hanggowibowo, and D. Nugraheny, "Sistem Pendukung Keputusan Penentuan Cuti Menggunakan Metode Technique for Order Preferences by Similarity to Ideal Solution (TOPSIS)," pp. 47-61.

[10] M. Azmi, Y. Sonatha, and Rasyidah, "Pemanfaatan Sistem Pendukung Keputusan Untuk Penentuan Alokasi Dana Kegiatan (Studi Kasus Unit Kegiatan Mahasiswa Politeknik Negeri Padang), 'J. Momentum, vol. 16, no. 1, pp. 75-83, 2014.

[11] F. A. S. Siti Yulia Rahma, "Sistem Pendukung Keputusan Alokasi Anggaran Menggunakan Metode Simple Additive Weighting Pada Smp Negeri 3 Satu Atap," SAINTEK (Jurnal Sains dan Teknol., vol. 1, no. 1, pp. 32-39, 2019.

[12] R. Riza, M. Hasbi, and I. A. Prabowo, "Sistem Pendukung Keputusan Penanganan Pasien Ugd Menggunakan Metode Fuzzy Multiple Attribute Decision Making Dengan Simple Additive Weighting Pada Puskesmas Gajahan Surakarta," J. Teknol. Inf. dan Komun., vol. 6, no. 1, pp. 21-28, 2018.

[13] K. Hasanah et al., "Sistem Seleksi Penerimaan Santri Online Pada Pondok Pesantren,” pp. 195-200, 2018.

[14] E. I. Chardina, "Sistem Pendukung Keputusan Penentuan Waktu Kerja Karyawan dengan Metode Analytical Hierarchy Process," no. April, 2009.

[15] M. Ridwan, "Prototype Sistem Pendukung Keputusan Untuk Penetapan Jadwal Kuliah Menggunakan 
Algoritma Genetika," Syst. Inf. Syst. Informatics J., vol. 2, no. 2, pp. 9-18, 2016.

[16] I. Laengge, H. F. Wowor, and M. D. Putro, "Sistem Pendukung Keputusan Dalam Menentukan Dosen Pembimbing Skripsi," J. Tek. Inform., vol. 9, no. 1, 2016.

[17] M. A. Nurdian, "Sistem Pendukung Keputusan Pemilihan Santri Berprestasi Pondok Pesantren Assyafi ’ Iyyah Kediri Dengan Metode Analitycal Hierarchy Process ( Ahp ),” pp. 1-9, 2016.

[18] Dedi, R. Tullah, and F. Khoir, "Sistem Pendukung Keputusan Siswa Berprestasi dengan Methode AHP," Gaodianya Jishu/High Volt. Eng., vol. 43, no. 9, pp. 2911-2918, 2017.

[19] R. Putra, I. Werdiningsih, and I. Puspitasari, "Sistem Pendukung Keputusan Pemilihan Siswa Berprestasi di Sekolah Menengah Pertama dengan Metode VIKOR dan TOPSIS," J. Inf. Syst. Eng. Bus. Intell., vol. 3, no. 2, p. 113, 2017.

[20] Sahmin, "Sistem Pendukung Keputusan Pemilihan Santri Terbaik di Madrasah Aliyah Swasta Dengan Menggunakan Metode ARAS," pp. 693-702, 2019.

[21] Nugroho Joko Usito, "Sistem Pendukung Keputusan Penilaian Proses Belajar Mengajar Menggunakan Metode Simple Additive Weighting (Saw)," J. Chem. Inf. Model., vol. 53, no. 9, pp. 1689-1699, 2013.

[22] Y. Irawan, Herianto, and S. O. Simamora, "Sistem Pendukung Keputusan untuk Menentukan Kegiatan Ekstrakurikuler Berdasarkan Bakat dan Minat Menggunakan Metode SAW (Simple Additive Weighting)," JTIM J. Teknol. Inf. dan Multimed., vol. 1, no. 3, pp. 198-205, 2019.

[23] W. T. Andarini, Daryanto, and L. A. Muharom, "Sistem Pendukung Keputusan Pemilihan Penjurusan pada SMA Negeri 1 Pakusari Menggunakan Metode Weighted Product," J. Chem. Inf. Model., vol. 53, no. 9, pp. 1689-1699, 2013.

[24] F. Z. Dellyana, Daryanto, and M. R. Pratama, "Sistem Pendukung Keputusan Penjurusan Siswa SMA Menggunakan Multifactor Evaluation Process,” vol. 7, pp. 219-232, 2014.

[25] A. Jamil, N. Kumaladewi, and Z. Bey, "Sistem Pendukung Keputusan Dalam Perekrutan Guru Menggunakan Model Analytical Hierarchy Process ( AHP ) Studi Kasus MI Irsyaduthalibin Sukabumi," vol. 4, no. 1, pp. 1-8, 2011.

[26] R. Dwinanto, P. Moengin, and S. Adisuwiryo, "Perancangan Sistem Pendukung Keputusan Untuk Pengendalian Persediaan Bahan Baku Pada Pt. Batarasura Mulia," J. Tek. Ind., vol. 7, no. 3, 2018.

[27] P. A. W. Santiary, P. I. Ciptayani, N. G. A. P. H. Saptarini, and I. K. Swardika, "SISTEM PENDUKUNG KEPUTUSAN PENENTUAN LOKASI WISATA DENGAN METODE TOPSIS," vol. 5, no. 5, pp. 621-628, 2018.

[28] A. S. Honggowibowo, A. Pujiastuti, and S. Suryanto, "Sistem Pendukung Keputusan Pemilihan Destinasi Wisata Favorit Di Propinsi Yogyakarta Dengan Metode Weighted Product (Wp) Berbasis Android," Compiler, vol. 6, no. 2, pp. 58-68, 2017. 